\title{
Water Intake on a Sandy Range as Affected By 20 Years of Differential Cattle Stocking Rates ${ }^{1}$
}

EDD D. RHOADES, LOWELL F. LOCKE, HOWARD M. TAYLOR, AND E. H. McILVAIN2

Research Agricultural Engineer, Chickasha, Oklahoma; Research Soil Scientist, Woodward, Oklahoma; Research Soil Scientist, Bushland, Texas; and Research Agronomist, Woodward, Oklahoma, respectively.

In the semiarid Southern Great Plains, forage production on a range site usually depends upon available soil moisture. In turn, available soil moisture depends upon (a) intensity, duration and frequency of precipitation; (b) water intake characteristics of the soil; (c) water retention and flow patterns within the soil profile; and (d) evaporation and transpiration characteristics of the soil surface and living vegetation.

Man has yet to exert significant control over precipitation within the Great Plains, but several investigators, Duley and Domingo (1949), Johnston (1962), Rauzi (1960), and Rauzi and Smika (1963), have shown that range conditions caused by grazing management will affect available soil moisture. Effects of grazing management and resultant vegetal cover on water intake and retention character-

\footnotetext{
${ }^{1}$ Contribution from the Soil and Water Conservation Research Division and the Crops Research Division, Agricultural Research Service, USDA, in cooperation with the Oklahoma Agricultural Experiment Station.

${ }^{2}$ Acknowledgment: The authors gratefully thank Ferris P. Allgood, Soil Scientist, and Jack E. Engleman, Range Conservationist, Soil Conservation Service, for selecting comparable Pratt soil profiles and determining range condition, respectively, on each study site.
}

istics have not been studied previously for Pratt and similar sandy soils of the Southern Great Plains. This investigation determined the effects of heavy, moderate, and light stocking rates with beef cattle during a 20-year period upon water intake and water retention characteristics of Pratt loamy fine sand soil.

\section{Location, Soil, And Vegetation}

The study was conducted on the Southern Plains Experimental Range located in northwestern Oklahoma near Woodward. Average annual precipitation is 22.82 inches, but it has varied from 9.97 inches in 1954 to 42.61 inches in 1957. About 70 percent of the annual precipitation falls during the April through September growing season. High-intensity thunderstorms occur frequently. Wind velocities and summer temperatures are normally high, and annual evaporation from a freewater surface is about 72 inches.

The experimental range is located on rolling, stabilized sand dunes composed of a mixture of Pratt, Tivoli, and Otero soil series. This study was restricted to Pratt loamy fine sand soil, which is dominant on the study area and is a major soil in the Rolling Red Plains land resource area. It has a weak, fine-granular, single-grained structure that is very friable when wet and soft when dry. The soil contains less than 5 percent clay and has a $\mathrm{pH}$ of about 6.6 in all horizons to 6 feet. The freely drained, deep, sandy Pratt soils occur on undulating to hummocky upland plains of western Oklahoma, southwestern Kansas, and the Texas Panhandle.

Native vegetation of the area is dominated by an overstory of sand sagebrush (Artemisia filifolia Torr.) with an average canopy cover of 38 percent. The basal cover of grasses and forbs averages about 8 percent, and an annual average of approximately 1,000 pounds of oven-dry forage is produced per acre.

\section{Procedure And Equipment}

In 1940 , the experimental range was divided into pastures that varied in size from 50 to 213 acres. Inside each pasture, a small area of about 3 acres was fenced to exclude grazing. Replicated treatments of heavy, moderate, and light stocking rates were initiated by putting beef cattle on these pastures in December 1941; therefore, nongrazed areas and areas that had been grazed continuously at each of three grazing intensities for 20 years were available. The average stocking rates, or grazing intensities, were: (a) nongrazed exclosure, (b) 22 acres per animal unit (light grazing), (c) 17 acres per animal unit (moderate grazing), and (d) 12 acres per animal unit (heavy grazing) . Stocking rates were adjusted on basis of current year's forage production, and the rates were heavier than average in wet years and lighter during droughts.

In the fall of 1961 , soil profiles were examined and sufficient 
gently-sloping ( 1 to 4 percent) sites of Pratt loamy fine sand were selected to permit fenceline comparisons between grazing treatments. Twelve locations or three sites for each of four treatments were selectd to minimize site differences.

During the fall of 1961 and the spring of 1962, water-intake rates of the grassed areas between sagebrush plants were characterized by two procedures: First, a trailer-mounted, double-tower sprinkling infiltrometer, as described by Rhoades (1961), was used to obtain measurements on six replications of 120 minutes duration from each of the 12 locations and, second, water-intake rates were obtained using the double-ring recording infiltrometer (Lock et al., 1960), with a 2-inch head maintained in each ring. Four replications of 60 minutes duration were used on sites near those used with the sprinkling infiltrometer. In addition, the effects of individual sagebrush plants upon the waterintake rates in heavily grazed pastures were measured with both infiltrometers. In these latter tests, six rings were placed directly around sagebrush plants and six were placed in adjoining grassed areas.

Prior to each sprinkling infiltration test, gravimetric moisture samples to a 4-foot depth were obtained on areas outside, but near, the intake rings, Moisture samples were obtained inside the intake rings 24 to 30 hours after completion of each intake test. These moisture samples were used to approximate field capacity.

Soil bulk density was determined by using a 2.8-inch-diameter core sampler. Samples were obtained by 2 -inch increments in the first foot of soil and by 4-inch increments near the middle of the second and third foot. Ten replications were used from the 0 - to 6 -inch depth and four replications from the 6- to 36-inch depth.
Soil penetration resistance measurements were made inside each sprinkled test plot 24 hours after sprinkling by using a modified Cornell recording penetrometer as reported by Terry and Wilson (1953).

Soil organic matter and nitrogen content were determined on samples obtained from duplicate pits at each of the 12 study sites. Samples were taken at 1-inch increments to the 6-inch depth and at 6-inch increments to the 24-inch depth. Organic matter was determined by the wet oxidation method and nitrogen content by the Kjeldahl method (Piper, 1950).

After completion of the infiltration tests, quantity of vegetation by species within infiltration rings was determined by clipping standing vegetation at the ground level (Figure 1). Litter and duff within each sprinkler ring were collected also. Samples were oven-dried and weighed. The basal cover-defined as percent of the ground area actually occupied by root crowns-was determined by the line-interception method for grass and forb species, and the foliage was determined for sagebrush (Parker and Savage,

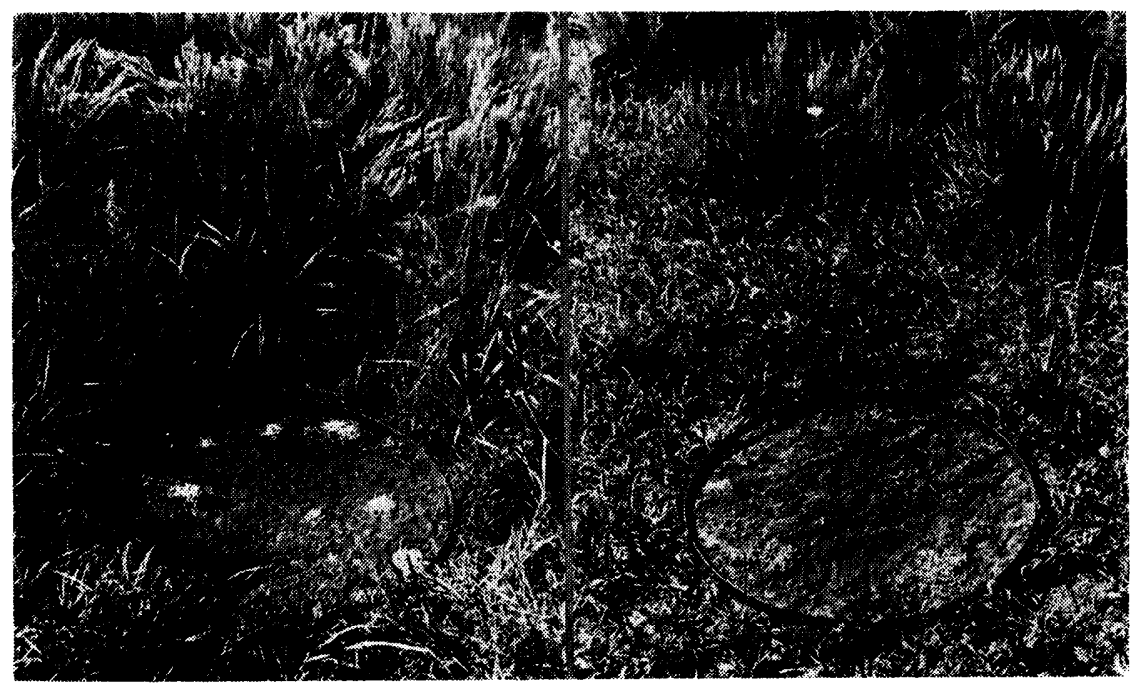

Figure 1. Typical views of sprinkling infiltrometer plots. Left-In a nongrazed exclosure with all surface vegetation removed, note scarcity of basal cover. Right-In a heavily grazed pasture, 12 acres per animal unit, with all surface vegetation removed, note abundant basal cover.
1944). Each of the 12 study sites was evaluated as to current range condition.

\section{Results And Discussion}

The water-intake rates were inversely proportional to the grazing intensity; that is, as the grazing intensity increased, the intake rate decreased. Average water-intake rates obtained with the sprinkling infiltrometer for the 2-hour periods were 2.27, 3.64, 4.41, and 10.58 inches per hour for the grassed areas of the heavily grazed, moderately grazed, lightly grazed, and the nongrazed pastures, respectively. Correlation between grazing intensity and water intake for this 2-hour period was significant at the 1-percent level.

After the first few minutes, water-intake rates with the sprinkling infiltrometer on the grazed areas increased with time, but the rates on the nongrazed areas remained relatively constant (Figure 2). The reason for the increasing water-intake rate with time is not known, but possibly it is associated with soilparticle wettability as noted by Jamison (1945) and Letey et al. (1962).

\section{Water Intake}




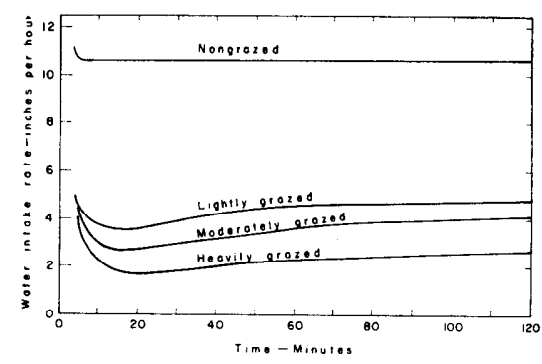

Figure 2. Average water intake rates obtained with the sprinkling infiltrometer.

The correlation of the infiltration rates with the sprinkler and the double-ring infiltrometers for the first hour of infiltration was highly significant. However, the intake rates with the doublering infiltrometer ranged from 2.33 to 3.16 times greater than those of the sprinkling infiltrometer (Figure 3). Swartzendruber and Olson (1961), using the double-ring infiltrometer, found that the true infiltration rate may be overestimated. There are at least three reasons for the higher intake rates from the double-ring infiltrometer: First, a 2-inch head of water was used with the double-ring infiltrometer, but the head was negligible in the sprinkler tests; second, impact from the falling drops of water should compact the soil surface in the sprinkler tests but not in the double-ring tests; and third, the surface area was smaller with the double-ring than with the sprinkler, thereby increasing the chances for lateral flow of soil water. Results from the sprinkling infiltrometer approximate actual intake rates; however, results from the double-ring infiltrometer pro-

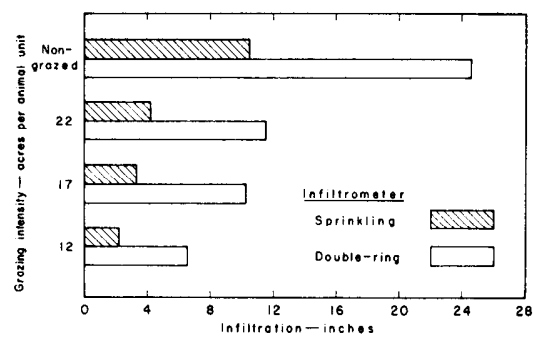

Figure 3. Comparison of total water intake during a one-hour period using two types of infiltrometers. vide valuable comparative data.

The average water-intake rate under sagebrush in one of the heavily grazed pastures with the sprinkling infiltrometer was 8.66 inches per hour or only slightly less than in the nongrazed exclosures. This was about 2.2 times greater than the intake rate on the grassed area between sagebrush plants. Sagebrush canopies covered about 38 percent of the land surface on both the grazed and nongrazed sites; therefore, the water-intake rates were obtained from areas representing about 62 percent of the land surface. The intake rates for all grazing treatments shown in Figure 2 should be increased to be representative of the sites.

These data show that grazing intensity is an important range management factor in absorbing and utilizing maximum precipitation on Pratt loamy fine sand and similar sandy soils in the Southern Great Plains.

\section{Other Soil Characteristics}

Bulk Density.-Soil bulk densities of the nongrazed sites were significantly lower to the 3-foot depth than those of the grazed sites (Table 1). Conversely, the bulk density at the heavy stocking rate was higher than the other treatments at all depths, but only in the 4- to 6-inch and the 12- to 24-inch depths were there significant differences at the 5-percent level among the three grazing treatments. During sampling, a large number of insect and rodent burrows were found in the exclosures and under the sagebrush plants. These burrows and the lack of cattle traffic account for most of the lower bulk density of the nongrazed sites.

Water Holding Capacity.When compared on a moisture content by weight basis, there were no apparent differences in field capacities associated with grazing intensities. Field $\mathrm{Ca}$ pacity-used here as total moisture held in the soil 24 to 30 hours after complete wetting of the soil profile-averaged from 8.3 to 9.5 percent by weight for the various stocking rates, but differences were insignificant. Permanent wilting point-used here as the lower limit of moisture held in the soil profile that is available for plant growthbased on previous tests, averaged about 2.0 percent moisture by weight for each stocking rate. Again the differences were insignificant. When the available soil moisture holding capacities were compared on a volumetric basis, the non-grazed sites retained significantly less available water in the 4-foot profile. The total amount of water needed to recharge the moisture reservoir of a 4-foot Pratt loamy fine sand profile was calculated at 4.90 inches for the nongrazed sites and 5.40 inches for the heavily grazed sites. This lower available water holding capacity on a volumetric basis is related to the lower bulk density of the nongrazed sites.

Penetrometer Pressure.-Penetration resistance of the soil

Table 1. Effect of differential stocking rates for 20 years on bulk density of Pratt loamy fine sand soil.

\begin{tabular}{|c|c|c|c|c|c|c|c|c|c|}
\hline \multirow[b]{2}{*}{ Treatment } & \multicolumn{9}{|c|}{ Depth (inches) } \\
\hline & $0-2$ & $2-4$ & $4-6$ & $6-8$ & $8-10$ & $10-12$ & $12-24$ & $24-36$ & Avg. \\
\hline & 一 & -- & -- & & $\mathrm{G} / \mathrm{cm}^{3}$ & -- & --- & -- & - \\
\hline 12 APAU $^{1}$ & $1.55^{\mathrm{a} 2}$ & $1.73^{a}$ & $1.72^{\mathrm{a}}$ & $1.63^{a}$ & $1.61^{\mathfrak{a}}$ & $1.68^{\mathrm{a}}$ & $1.62^{\mathfrak{a}}$ & $1.62^{\mathrm{a}}$ & 1.63 \\
\hline 17 APAU & $1.52^{a}$ & $1.68^{a}$ & $1.66^{b}$ & $1.62^{\mathrm{a}}$ & $1.60^{\mathfrak{a}}$ & $1.60 \mathrm{ab}$ & $1.56^{b}$ & $1.60^{\mathrm{a}}$ & 1.59 \\
\hline 22 APAU & $1.52^{\mathrm{a}}$ & $1.68^{\mathrm{a}}$ & $1.63^{b}$ & $1.62^{\mathrm{a}}$ & $1.59^{a}$ & $1.59 \mathrm{ab}$ & $1.55^{b}$ & $1.59^{\mathrm{a}}$ & 1.58 \\
\hline Nongrazed & $1.44^{\mathrm{b}}$ & $1.47^{b}$ & $1.56^{c}$ & $1.57^{\mathrm{a}}$ & $1.53^{b}$ & $1.57^{\mathrm{b}}$ & $1.41 \mathrm{c}$ & $1.50^{b}$ & 1.48 \\
\hline
\end{tabular}

1 Acres per animal unit

${ }^{2}$ Comparable averages for each depth increment with different superscripts are significantly different at the 5-percent level 
at field-capacity moisture, measured in pounds per square inch, was greatest on the heavily grazed sites and least on the nongrazed sites. Averages of 90 measurements per site to a depth of 12 inches were:

$\begin{array}{lc}\begin{array}{c}\text { Stocking } \\ \text { rate }\end{array} & \begin{array}{c}\text { Pressure, lbs. } \\ \text { per sq. in. }\end{array} \\ \text { Heavy } & 58.4^{\mathrm{a}} 3 \\ \text { Moderate } & 37.9^{\mathrm{bc}} \\ \text { Light } & 53.6^{\mathrm{ab}} \\ \text { Nongrazed } & 24.3^{\mathrm{c}}\end{array}$

Although some of the average penetrometer pressures were significantly different, the reason for the reversal of the data from the lightly and moderately stocked sites is not known.

Organic Matter. - Although the differences in organic matter, due to stocking rate, were small and insignificant, there was slightly more organic matter in the top 2 feet of soil in the nongrazed plots than in the grazed plots. The organic matter content for all treatments averaged $0.95,0.44,0.34$, and 0.26 percent for the 0 - to 6-, 6- to $12-$, $12-$ to $18-$, and 18- to 24-inch depths, respectively.

Nitrogen Content. - Differences in soil nitrogen content due to stocking rate were essentially nonexistent. The nitrogen content for all treatments averaged $0.044,0.026,0.020$, and 0.016 percent for the 0 - to $6-, 6$ to $12-, 12-$ to $18-$, and $18-$ to 24-inch depths, respectively. These data differ greatly from those reported from North Dakota by Rogler and Smika (1962). They found that soil nitrogen in pastures heavily grazed for 46 years was higher than in the moderately grazed pastures. The North Dakota study was conducted on a silt loam soil with a nitrogen content about 10 times greater than the Pratt soil at Woodward.

${ }^{3}$ Comparable averages with different superscripts are significantly different at the 5-percent level.
Soil Loss.-Soil loss in the runoff water and in the splash from the sprinkling infiltrometer tests on slopes ranging up to 6 percent was essentially non-existent on all grazed and nongrazed sites. The runoff water was usually clear and free of soil material even on the heavily grazed sites.

\section{Vegetation}

Total quantity of all attached forage and all detached litter averaged 12,600 pounds per acre for the nongrazed, 5,900 pounds per acre for the lightly grazed, 5,500 pounds per acre for the moderately grazed, and 4,100 pounds per acre for the heavily grazed pastures (Table 2). This decrease in amount of vegetative cover associated with the increase in stocking rate is a major reason for the decrease in waterintake rates. However, the increase in soil bulk density with increasing stocking rate also contributed to the change in intake rates.

The untrampled and uneaten tall-grass production, 3,300 pounds, from the current and previous year's growth on the nongrazed plots plus the great quantity of litter and duff, 8,500 pounds, formed a protective mantle on the soil that far exceeded the covering on the lightly grazed plots. The correlation of range condition class and water-intake rate was highly significant.

The percent of basal cover increased as the stocking rate increased. With the increased grazing intensity, the taller grass species such as sand bluestem (Andropogon hallii Hack.), little bluestem (A. scoparius Michx.), switchgrass (Panicum virgatum L.), and sand lovegrass (Eragrostis trichodes (Nutt.) Wood) were replaced by the shorter sod-forming grasses including blue grama (Bouteloua gracilis (H.B.K.) Lag. ex Steud.), sand dropseed (Sporobolus cryptandrus (Torr.) A. Gray), fall witchgrass (Leptoloma cogna- tum (Schult.) Chase), and sand paspalum (Paspalum stramineum Nash). The greatest basal cover of living vegetation was found in the heaviest grazed pastures, but these pastures contained the smallest quantity of litter and standing forage and possessed the lowest water-intake rate.

These tests indicate that soil bulk density and quantity of vegetal cover, which may change with time and are related to climatic conditions and to the degree of grazing use, greatly influence the ability of the land to absorb rainwater as it falls.

\section{Rainfall and Useable Soil Moisture}

Most rainstorms in the area produce less than 2 inches of rainfall; however, rains of high intensity and short duration result in excessive runoff from the Pratt soils. Expected rainfall intensity-frequency data, as compiled by Yarnell (1935), indicate that rainfall intensities of 5.04 , 4.50 , and 3.60 inches per hour for durations of 5,10 , and $15 \mathrm{~min}$ utes, respectively, are expected to occur at least once every 2 years in this area. Thus, one should expect substantial runoff on all of the grazed sites, but only rarely would runoff occur on the nongrazed sites. Observations during the 20-year differential grazing period showed that runoff actually did occur numerous times on all grazed areas. Much of this runoff accumulated in the depressional areas of the dune topography and aided the available moisture supply of the depressions.

Differences in moisture retention caused by changes in bulk density may slightly affect the total moisture supply of the sites. A small summertime rain that penetrates the soil will be more effective in producing plant growth on soil with a lower bulk density, because less of the infiltered water will be held near the soil surface where evaporation is more rapid. Therefore, a 
Table 2. Vegetation, litter, and range condition class on sprinkled infiltration plots in relation to pasture stocking rates

\begin{tabular}{|c|c|c|c|c|c|c|c|c|c|c|c|c|c|c|}
\hline \multirow{3}{*}{$\begin{array}{l}\text { Stocking } \\
\text { rate }\end{array}$} & \multicolumn{6}{|c|}{ Standing vegetation } & \multicolumn{6}{|c|}{ Litter } & \multirow{3}{*}{$\begin{array}{l}\text { Total } \\
\text { vegetation } \\
\text { and } \\
\text { litter }\end{array}$} & \multirow{3}{*}{$\begin{array}{l}\text { Range } \\
\text { condition } \\
\text { class }\end{array}$} \\
\hline & \multicolumn{3}{|c|}{ Grass } & \multirow{2}{*}{\multicolumn{2}{|c|}{ Forbs Sage }} & \multirow[b]{2}{*}{ Total } & \multirow[b]{2}{*}{ Grass } & \multirow[b]{2}{*}{ Forbs } & \multirow[b]{2}{*}{ Sage } & \multirow{2}{*}{\multicolumn{2}{|c|}{ Manure Duff }} & \multirow[b]{2}{*}{ Total } & & \\
\hline & Tall' & Short ${ }^{2}$ & Total I & & & & & & & & & & & \\
\hline--- & --- & -- & -- & $-(\mathrm{Po}$ & unds & per ac & re, ove & n-dry) & -- & -- & -- & --1 & --- & \\
\hline Heavy; 12 APAU3 & 50 & 1,550 & 1,600 & $\mathbf{T}$ & 50 & 1,650 & 650 & 40 & 260 & 40 & 1,460 & 2,450 & $4,100^{\mathrm{a} 6}$ & Fair \\
\hline Moderate; 17 APAU & 230 & 1,340 & 1,570 & 10 & $\mathrm{~T}^{5}$ & 1,580 & 830 & 60 & 390 & 540 & 2,100 & 3,920 & $5,500^{\mathrm{a}}$ & Low good \\
\hline Light; 22 APAU & 100 & 1,270 & 1,370 & 30 & 50 & 1,450 & 1,140 & 180 & 630 & 0 & 2,500 & 4,450 & $5,900^{\mathrm{a}}$ & Good \\
\hline Nongrazed & $3,300^{4}$ & 300 & 3,600 & 50 & 450 & 4,100 & 1,800 & 600 & 1,270 & 0 & 4,830 & 8,500 & $12,600^{\mathrm{b}}$ & Excellent \\
\hline \multicolumn{7}{|c|}{ (Basal density, percent of ground area) } & & & & & & & & \\
\hline Heavy; 12 APAU & 0.3 & 23.3 & 23.6 & 0.0 & 0.6 & $24.2^{\mathrm{a}}$ & & & & & & & & \\
\hline Moderate; 17 APAU & 1.3 & 18.6 & 19.9 & .1 & .2 & $20.2^{\mathrm{a}}$ & & & & & & & & \\
\hline Light; 22 APAU & .5 & 10.9 & 11.4 & .1 & .4 & $11.9^{\mathrm{b}}$ & & & & & & & & \\
\hline Nongrazed & 4.4 & 2.4 & 6.8 & .1 & 1.3 & $8.2^{\mathrm{b}}$ & & & & & & & & \\
\hline
\end{tabular}

1Sand bluestem, little bluestem, switchgrass, and sand lovegrass.

2All grass other than tall grass; predominantly sand dropseed, blue grama, sand paspalum, and fall witchgrass.

${ }^{3}$ Acres per animal unit.

4Includes dead standing vegetation from 1 or more years of age.

5Trace.

${ }^{6}$ Comparable averages with different superscripts are significantly different at the 5-percent level.

small rain on the lightly grazed sites may be more effective in producing plant growth than on the heavily grazed sites. However, limited observations show that the amount of rain that is intercepted and held for ready evaporation is proportional to the amount of vegetal cover. A large amount of infiltered water may be more effective in producing plant growth on the heavily grazed sites, because more of the water will be retained in the root zone. Differences in effective rooting depth of the plants growing on the various grazingintensity sites and differences in quantity and intensity of each rainstorm may erase or enhance these moisture retention considerations.

\section{Summary}

Water relations for a Pratt loamy fine sand on the Southern Plains Experimental Range in northwestern Oklahoma were investigated after four levels of continuous cattle grazing had been imposed for 20 years. Water-intake rates were determined with a sprinkling infiltrometer and with a doublering infiltrometer. In addition, the following measurements were obtained from each level of grazing: Soil moisture retention, bulk density, penetration resistance, organic matter, nitrogen content, vegetative cover, and basal cover.

Water-intake rates were inversely proportional to the grazing intensity, regardless of the type of equipment used to approximate intake rates. There was a high correlation between the intake rates measured with the sprinkling infiltrometer and the double-ring infiltrometer; however, the intake rates with the double-ring infiltrometer were about 2 to 3 times greater than those with the sprinkling infiltrometer.

Bulk density and penetrometer measurements showed that grazing compacted the soil. Therefore, grazing intensity affected the quantity of water retained at field capacity and at wilting point. The heavily grazed sites retained about 0.5 inch more water in a 4-foot profile than did the nongrazed sites.

Soil organic matter and nitrogen content decreased as depth of soil increased, but neither organic matter nor nitrogen content was significantly affected by stocking rate.

Soil loss in the runoff water and in the splash from the sprin- kling infiltrometer tests was negligible, even on the heavily grazed sites.

A soil-protecting cover of about 6 tons of standing vegetation and litter per acre was found on the nongrazed sites, whereas 2 to 3 tons were found on the grazed sites. Quantity of vegetative cover, both living and dead, and range condition class were correlated with the waterintake rates. The short, sodforming grasses predominated under heavy grazing and tall bunch grasses predominated on the nongrazed sites.

\section{LITERATURE CITED}

Duley, F. L. AND C. E. Domingo. 1949. Effect of grass on intake of water. Nebr. Agr. Expt. Sta. Res. Bul. 159: 1-15.

JAMrson, V. C. 1945. The penetration of irrigation and rain water into sandy soils of Central Florida. Soil Sci. Soc. Amer. Proc. 10: 25-29.

Johnston, Alexandfr. 1962. Effects of grazing intensity and cover on the water-intake rate of fescue grassland. Jour. Range Mangt. 15: 79-82.

Letey, J., J. Osborn, ANd R. E. PeliSHEK. 1962. The influence of watersolid contact angle on water movement in soil. Bul. Internatl. Assoc. Sci. Hyd. 3: 75-81.

Locke, L. F., H. V. Eck, B. A. StewART, AND H. J. HAAS. 1960. Plow- 
pan investigations at the Great Plains Field Stations, Woodward, Oklahoma, and Mandan, North Dakota. U. S. Dept. Agri. Prod. Res. Rept. No. 40. Washington, D. C. $33 \mathrm{pp}$.

Parker, K. W. AND D. A. Savage. 1944. Reliability of the line interception method in measuring vegetation on the Southern Great Plains. Jour: Amer, Soc. Agron. 36: 97-110.

PIPER, C. S. 1950. Soil and plant analysis. Interscience Publishers, Inc., New York.

RAUZI, FRANK. 1960. Water-intake studies on range soils at three locations in the Northern Plains. Jour. Range Mangt. 13: 179-184.

RaUzi, Frank and Darryl E. SMika. 1963. Water intake on rangeland as affected by simulated grazing and fertilization. Jour. Range Mangt. 16: 125-128.

RHoAdes, EdD D. 1961. A mobile double-tower sprinkling infiltrometer. Jour. Soil and Water Cons. 16: 181-182.

Rogler, George A. ANd Darryl E. SmIKa. 1962. A 46-year comparison of two intensities of grazing on the vegetation, beef production, and soil fertility of the Northern Plains Rangelands. Jour. Range Mangt. Abstract of Papers, 15th Ann. Meeting, Jan. 23-26.

SWARTZENDRUber, Dale aNd T. C. OLsoN. 1961. Sand-model study of buffer effects in the double-ring infiltrometer. Soil Sci. Soc. Amer. Proc. 25: 5-8.

TerRY, C. W. AND H. M. WILSON. 1953. The soil penetrometer in soil compaction studies. Agr. Engr. 34: 831-834.

YARNELL, David L. 1935. Rainfall intensity-frequency data. U. S. Dept. Agr. Misc. Pub. 204. 67 pp. 